\title{
FRICTION OF A STEEL BALL ON A SINGLE GRYSTAL OF ICE
}

\author{
By Katutosi Tusima \\ (Institute of Low Temperature Science, Hokkaido University, Sapporo, Japan o6o)
}

\begin{abstract}
This paper presents the results of a study carried out to explain the low friction on ice. Friction of a steel ball on a single crystal of ice was measured as a function of load, velocity, temperature, and diameter of slider. It was found that even when the velocity was very small $\left(1.5 \times 10^{-7}\right.$ to $\left.1.8 \times 10^{-3} \mathrm{~m} / \mathrm{s}\right)$, the coefficient of friction was very small ranging from 0.005 to 0.2 , although friction on the prismatic plane was twice as large as that on the basal plane. The coefficient of friction increased with load, which means that Amonton's classical law of friction is not applicable to ice. The coefficient of friction increased with decreasing velocity, which may result from the creep of ice in the contact area. The friction strongly increased as the temperature became close to $0^{\circ} \mathrm{C}$. A minimum friction was observed for a definite temperature. It was found that the explanation of the results obtained is given satisfactorily neither by the classic pressuremelting theory nor by the friction-melting theory, but only by adhesion theory.

RÉsumÉ. Frottement d'une bille d'acier sur la surface d'un monocristal de glace. Ce papier présente les résultats d'une étude ayant pour but d'expliquer le faible frottement de la glace. Le frottement d'une bille d'acier sur un monocristal de glace est mesuré en fonction de la charge, de la vitesse, de la température et du diàmètre de la bille. On a trouvé que, même lorsque la vitesse était très faible $\left(1,5 \times 10^{-7} \mathrm{a} 7,4 \times 10^{-3} \mathrm{~m} / \mathrm{s}\right.$, le coefficient de friction était très petit allant de 0,005 à 0,2 , bien que la friction sur la face prismatique soit deux fois plus forte que sur la face de base. Le coefficient de friction croît avec l'augmentation de la charge ce qui signifie que la loi classique de friction d'Amonton n'est pas applicable à la glace. Le coefficient croît lorsque la vitesse de glissement est réduite ce qui peut être dû au fluage de la glace sur la zone de contact. Le frottement augmente considerablement lorsque la température de la glace se rapproche de $o^{\circ} \mathrm{C}$. Un minimum de frottement est observé pour une température qui a été définie. On a trouvé que l'explication des résultats fusion, ni par la théorie frottement-fusion, mais seulement par la théorie de l'adhésion.

Zusammenfassung. Reibung einer Stahlkugel auf der Oberfäche von Eis-Einkristallen. Diese Arbeit vermittelt die Ergebnisse einer Untersuchung, mit der die niedrige Reibung von Eis. Die Reibung einer Stahlkugel auf einem Eis-Einkristall wurde in Abhängigkeit der Last, Geschwindigkeit, Temperatur und des Durchmessers der Kugel gemessen. Es zeigte sich, dass selbst wenn die Gleitgeschwindigkeit sehr klein war $\left(1,5 \times 10^{-7}\right.$ bis $\mathrm{r}, 8 \times \mathrm{IO}^{-3} \mathrm{~m} / \mathrm{s}$ ) der Reibungskoeffizient sehr klein und zwar im Bereich zwischen 0,005 und 0,2 war; auf der prismatischen Ebene war die Reibung allerdings doppelt so gross wie auf der Basisebene. Der Reibungskoeffizient wuchs mit der Last, was bedeutet, dass das klassische Reibungsgesetz von Amonton auf Eis nicht anwendbar ist. Der Koeffizient wuchs, wenn die Gleitgeschwindigkeit verringert wurde, was auf das Kriechen des Eises an der Kontaktfläche zurückzuführen sein mag. Die Reibung nahm stark zu, wenn die Temperatur sich $0^{\circ} \mathrm{C}$ näherte. Ein Minimum der Reibung wurde für eine gewisse Temperatur beobachtet. Es zeigte sich, dass die gewonnenen Ergebnisse weder durch die klassische Druckschmelztheorie noch durch die Reibungsschmelztheorie, sondern nur durch die Adhäsionstheorie befriedigend erklärt werden können.
\end{abstract}

\section{INTRODUGTION}

Ice is perhaps one of the lowest frictional materials on the Earth. The abnormally low friction allows us to perform various winter sports, such as ski-ing and sledging, and makes possible the transportation of heavy goods on snow and ice. On the other hand, it reduces the trafficability of vehicles throughout winter season in snowy and icy areas.

Why is friction on ice so low? It has been known since ancient times that a liquid lubricant, such as oil, can reduce friction between solid materials. Therefore, many scientists have analogously accepted that liquid water may be formed at the interface between a slider and ice. Two theories have been proposed to explain the formation of liquid water at the interface: one is the pressure-melting theory of Joly (1887) and Reynolds (1899), the other is the frictionmelting theory of Bowden and Hughes (1939).

The pressure melting theory has been abandoned by many workers because the normal pressure applied to the ice through the contact area was usually not enough to melt the ice. The friction-melting theory has been accepted by Bowden (1953, r955), Shimbo (r96r) and Barnes and others (I97I) as the most satisfactory theory to explain the formation of liquid water at the interface. Although different theories have been developed by McConica (vapour lubrication, see Mantis, I95I, p. 15) and Niven (rotation of ice molecules, r959), reliable confirmation of these theories has not been made. 
Although liquid water has actually been observed at the interface between ice and other materials during high-speed friction as reported by Huzioka (1962, 1963) and Tusima and Yosida (1969), it may nevertheless be unreasonable to conclude directly that the low friction of ice is attributable to lubrication by melt water at the interface for the following reasons.

First, even at very low friction velocities at which no melting can take place, the coefficients of friction obtained were as small as those observed at a high velocity as reported by Tabor and Walker (1970), Barnes and others (197I) and Schultz and Knappwost (r968). This strongly suggests that the low friction of ice is not caused by the existence of melt water.

Secondly, if it were perfect fluid lubrication, the coefficient of friction could be as low as 0.0004 as calculated by Evans and others (1976). Such a low value is expected to be impossible in reality.

Thirdly, the energy used for melting is extremely small (a few per cent) in comparison with the total amount of frictional energy as shown by Huzioka (1963) and Evans and others (1976). This means that melt water plays only a small role in friction.

Fourthly, it seems to be difficult to explain the effects of thermal conductivity of the slider on friction, as pointed out by Huzioka (1963), Pfalzner (1947) and Niven (1956).

It may be said, therefore, that the low friction of ice cannot be well explained by the friction-melting theory. However the low friction on ice can be understood by the adhesion theory. According to this theory, the coefficient of friction $\mu$ is expressed by using the shear strength $s$ of an adhesion junction and the yield pressure $p$ which is expressed in terms of Brinnel hardness $p$ :

$$
\mu=s / p \text {. }
$$

For metals, the value of $s$ is approximately half that of $p$, so that $\mu$ becomes to be of the order of 0.5 , which agrees well with that obtained by the experimental studies of friction of metals as shown in Table I. For ice, the value of $p$ is of the order of those of copper, but the value of $s$ is extremely small in comparison with those of metals. Typical values of $s$ and $p$ are, respectively, io bar (Raraty and Tabor, I968) and $10^{3}$ bar (Butkovich, 1954) at $-10^{\circ} \mathrm{C}$ and an indentation time of I s. Substituting these values into Equation (I), one obtains the coefficient of friction $\mu$ of ice is $0.0 \mathrm{I}$, which is of the same order of magnitude as those obtained in the experiments. This suggests a possibility that the low friction of ice can be explained by the adhesion theory.

TABle I. Brinnel hardNEss $p$ SHEAR STRENGTH $s$ AND RATIO $s / p$ For ICE AND SOME METALS

\begin{tabular}{|c|c|c|c|}
\hline Material & $\begin{array}{c}\text { Brinnel hardness* } \\
p \\
\text { bar }\end{array}$ & $\begin{array}{c}\text { Bulk shear strength } \dagger \\
s \\
\text { bar }\end{array}$ & $\mu=s / p$ \\
\hline Ice & I $000_{+}^{+}$ & 25 & 0.03 \\
\hline Iron & 10000 & 9000 & 0.9 \\
\hline Copper & 2500 & I 600 & 0.6 \\
\hline Lead & 400 & 75 & 0.2 \\
\hline Indium & 100 & 22 & 0.2 \\
\hline
\end{tabular}

However, if one wishes to clarify the mechanism of friction between any two materials, it is necessary to measure accurately a real contact area between them. Though the real contact area is believed to be of the order between $\mathrm{IO}^{-3}$ and $1 \mathrm{O}^{-4}$ of the apparent contact area in case of metals, there is a great uncertainty in estimating the real contact area when friction is produced between the flat surface of ice and the other material. This difficulty may, however, be overcome by observing friction between a loaded rigid spherical body and a 
flat surface of ice, because the sphere indents the ice surface, making the real contact area close to the apparent contact area. In such friction, the rigid sphere ploughs up a thin layer of ice which causes heavy strain and micro-fracture in the ice near the contact area. However, the effects of ploughing, strain and fracture on the coefficient of friction of ice can be estimated from the theoretical formula which Bowden and Tabor (1950) derived from the adhesion theory. Thus, this difficulty may be overcome.

For the reasons described above, the present author conducted a series of experiments on friction between a steel ball and a flat ice surface. The main purpose of this paper is to describe the experimental results and to interpret them from the standpoint of the adhesion theory.

\section{Experimental apparatus}

The apparatus is shown schematically in Figure I. A rectangular-shaped ice sample was frozen onto an acrylite disk A, which was mounted on a metal block M. The block m was driven either forwards or backwards on the upper surface of the thick rigid framework by a motor through reduction worm gears, and the ice sample on it was moved at a constant speed ranging from $1.5 \times 10^{-7}$ to $7.4 \times 10^{-3} \mathrm{~m} / \mathrm{s}$.

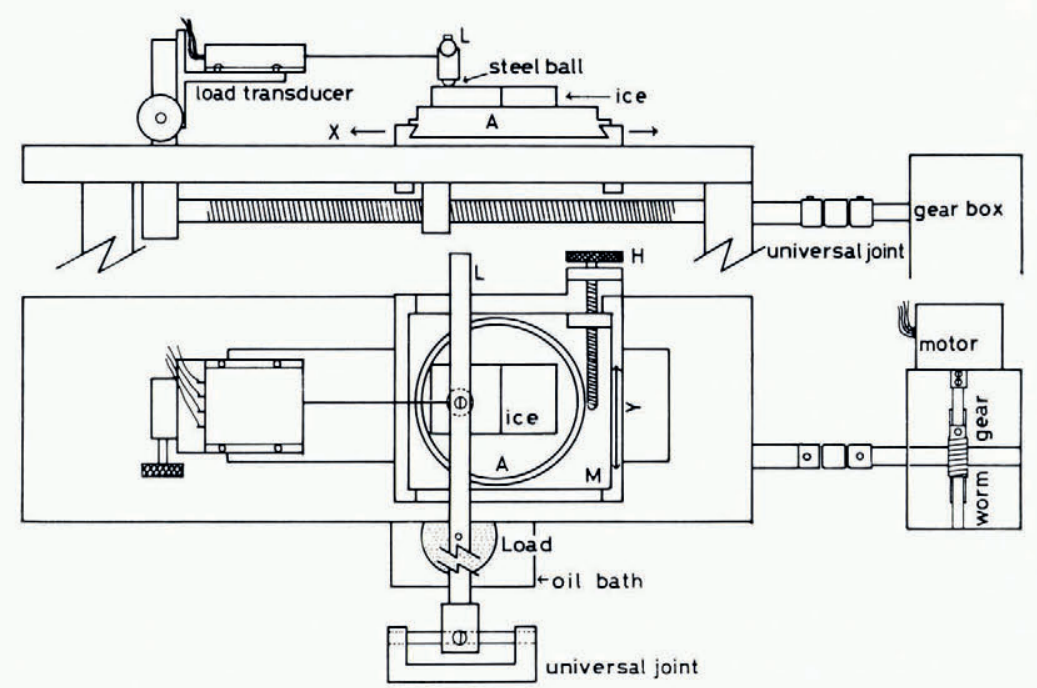

Fig. I. Schematic diagram of the experimental apparatus.

A steel ball, $6.4 \mathrm{~mm}$ in diameter, contacting the ice surface was mounted and fixed to a brass cylinder, to the top of which a metal lever $\mathrm{L}$ was firmly fixed. One end of the lever was free, while the other end was connected to a universal joint. A load which ranged from 0.4 to 3 I N, was exerted onto the ice surface by suspending a weight from the lever. The weight which corresponds to a given load was immersed in an oil bath that prevented the weight from shaking.

The friction force between the fixed steel ball and the moving ice surface was continuously measured by the use of a force-measuring system which consisted of a transducer, a bridgebox, a strain meter and a recorder. The ice sample can be shifted in the transverse direction by moving the mount $\mathrm{m}$ so that each friction run may be made on a virgin ice surface. The ice sample can also be rotated into any horizontal orientation by turning the disk A so as to measure the friction force on ice for various crystallographic orientations. 
ICE SAMPLES AND STEEL BALL

Tyndall figures were artificially produced at a corner of a large single crystal of ice collected from the Mendenhall Glacier, Alaska. By the aid of the Tyndall figures, two rectangular ice pieces were simultaneously cut out from the ice crystal in a way in which the frictional surface of the one was set parallel to the crystallographic basal plane (ooor) and that of the other parallel to the prismatic plane (o I $\overline{\mathrm{I}} \mathrm{O})$. These two pieces were placed side by side and frozen to an acrylite disk so as to form a bicrystal sample of ice. This sample was annealed for several hours at $-3^{\circ} \mathrm{C}$, and then the upper surface was turned on a lathe. It was annealed again at $-3^{\circ} \mathrm{C}$ until the turned surface became glossy like a mirror, and then
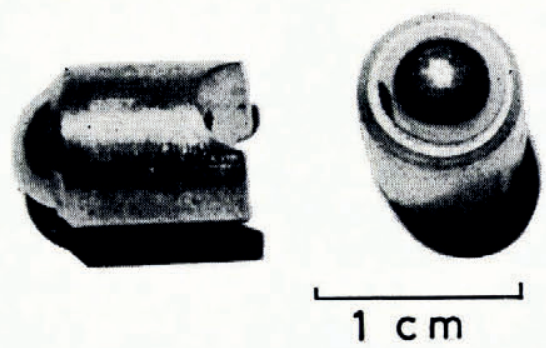

Fig. 2. A steel ball slider mounted on a brass cylinder.

brought into a cold room at an experimental temperature of -0.5 to $-30^{\circ} \mathrm{C}$. When it was exposed to a lower temperature than $-10^{\circ} \mathrm{C}$, its surface occasionally became cloudy. Samples with surfaces becoming cloudy were excluded from the experiment, and only samples with glossy surfaces were used for experimental studies on friction.

Steel balls with different sizes ranging from 1.6 to $12.7 \mathrm{~mm}$ in diameter were used in the experiment, for most of which a ball of $6.4 \mathrm{~mm}$ in diameter was used. The steel ball was cleaned by immersing it in an ultrasonic cleaning-bath filled with a mixture of alcohol and acetone and then in a bath filled with distilled water. The ball was cleaned again by washing it in the bath of distilled water and dried under an ultra-violet lamp.

\section{EXPERIMENTAL RESULTS}

\section{(I) Friction curve}

It was observed that friction on the prismatic plane is twice as large as that on the basal plane as illustrated in Figures 3 and 7. As seen in Figure 3, the friction force fluctuates more on the prismatic plane than on the basal plane, and it abruptly decreases at the grain boundary between the two crystals composing the bicrystal ice sample.

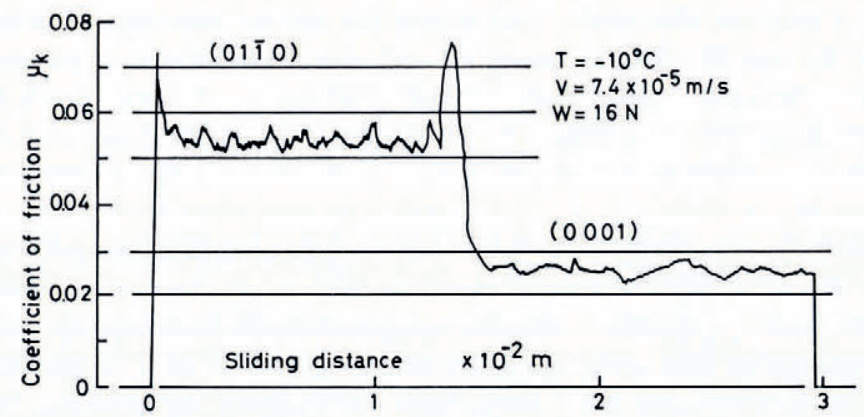

Fig. 3. A typical friction curve of a steel ball on ice. 


\section{(2) Load effect}

The effect of load on friction was studied. As an example, the coefficient of friction $\mu_{\mathrm{k}}$ for both the basal and prismatic planes, at a sliding velocity of $7.4 \times 10^{-5} \mathrm{~m} / \mathrm{s}$ and at a temperature of $-10^{\circ} \mathrm{C}$, was plotted against the lower range of loads, less than $5 \mathrm{~N}$, for both cases, while it linearly increased with the increase in load in the higher range of load. A similar tendency to that in Figure 4 was observed for different sliding velocities as seen in Figure 7 .

The friction $F$ in the present experiment is composed of two factors: $F=F_{\mathrm{s}}+F_{\mathrm{p}}$, where $F_{\mathrm{s}}$ and $F_{\mathrm{p}}$ respectively are concerned with the adhesion of ice and the ploughing of ice. $F_{\mathrm{s}}$ and $F_{\mathrm{p}}$ are, respectively, proportional to $A / W$ and $A^{\star} / W$, in which $W$ is the load applied, and $A$ and $A^{\star}$ are the contact area and the ploughed area, respectively. It was found in the experiment that the ratio $A / W$ is constant for any load, but the ratio $A^{\star} / W$ increases with increasing load as shown in Figure $4(\mathrm{~b})$. Since the ploughing area $A^{\star}$ was so small in the lower range of load, the ploughing effect was very small as compared with the sliding effect. It may, therefore, be concluded that the increase of $\mu_{\mathrm{k}}$ in the higher range of load may be attributed to the increase of the ploughing effect.
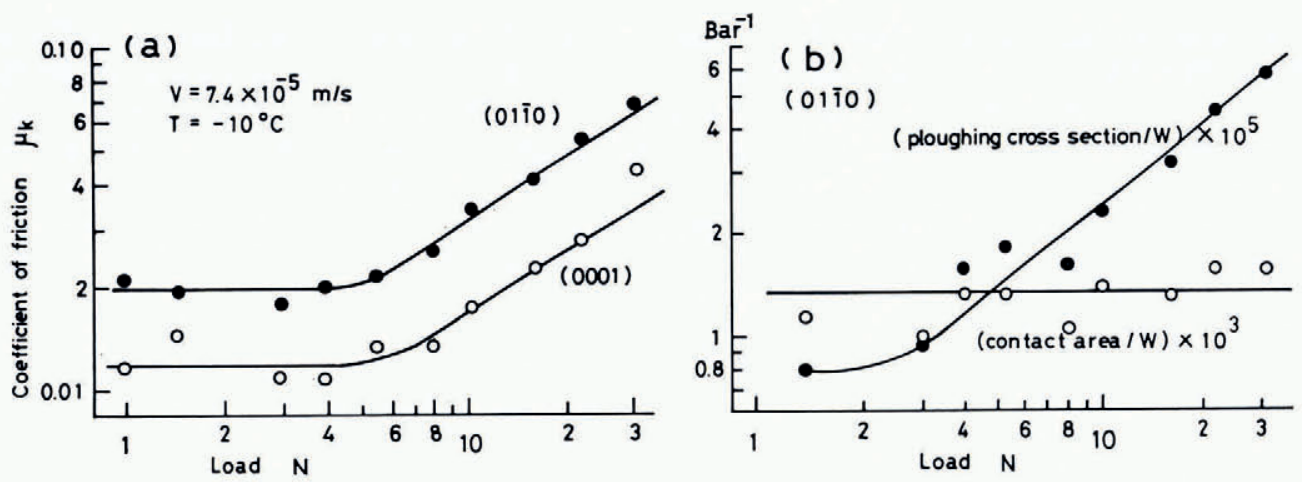

Fig. 4. (a) Dependence of friction on load for a basal and a prismatic plane of ice. (b) Contact area and ploughing cross-section against load.

\section{(3) Velocity dependence of friction}

In order to clarify the dependence of the friction of ice on sliding velocity, the friction force was measured with different sliding velocities for various loads. A typical example of the results obtained is shown in Figure 5, in which the coefficient of friction $\mu_{\mathrm{k}}$ is plotted against the sliding velocity obtained for both the basal and prismatic planes. As seen in this Figure, $\mu_{\mathrm{k}}$ decreases with an increase in the sliding velocity $V$. The width $\phi$ of the track of the ball was also measured for each run of the experiment, and a similar tendency was obtained between $\phi$ and $V$ to that obtained between $\mu_{\mathrm{k}}$ and $V$. This shows that the larger friction at lower sliding velocities can be attributed to the larger plastic deformation of ice at the contact area.

\section{(4) Temperature dependence of friction}

The coefficient of friction $\mu_{\mathrm{k}}$ and the width of the sliding track $\phi$ are respectively plotted in Figure 6(a) and (b) against the ice temperature when the temperature was raised from $-20^{\circ} \mathrm{C}$ up to $-\mathrm{I}^{\circ} \mathrm{C}$ at a rate of $\mathrm{I} .5 \mathrm{deg} / \mathrm{h}$. It was found that friction reaches a minimum value at a temperature of, in one instance, $-7^{\circ} \mathrm{C}$ when the sliding velocity is $7.4 \times 10^{-5} \mathrm{~m} / \mathrm{s}$ and the load is $4.8 \mathrm{~N}$. As seen in this figure, the friction at a temperature below the temperature of minimum friction increases on lowering the temperature, which is due to the increase 

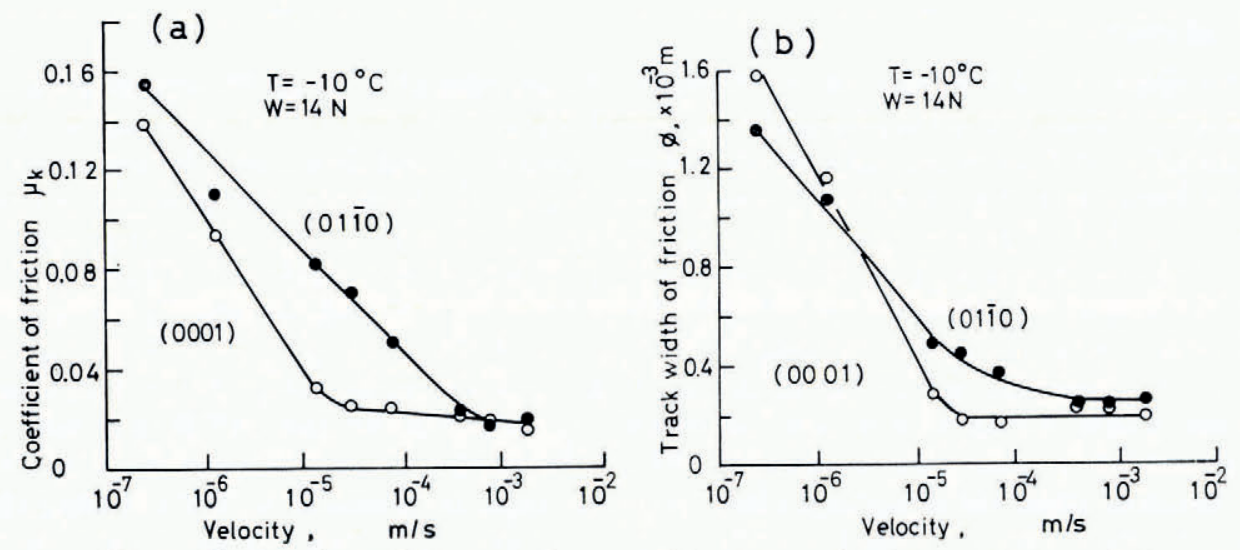

Fig. 5. (a) Dependence of friction on velocity, and (b) the width of a sliding track against load.

of shearing strength of ice at the lower temperature (Butkovich, I954; Tusima and Fujii, 1973). The friction at higher temperatures above the temperature of minimum friction markedly increases as the ice temperature approaches its melting point. This increase may be closely related to the increase in the width of the sliding track as shown in Figure $6(\mathrm{~b})$. We may conclude that the increase in the friction is caused by the ploughing of ice at the contact area. It should be noted that the temperature of minimum friction shifted to a higher temperature as the friction velocity was reduced. For example, it was at $-4{ }^{\circ} \mathrm{C}$ and $-2^{\circ} \mathrm{C}$ when the velocity was $\mathrm{I} .5 \times 1 \mathrm{IO}^{-5}$ and $\mathrm{I} .2 \times 10^{-6} \mathrm{~m} / \mathrm{s}$, respectively.
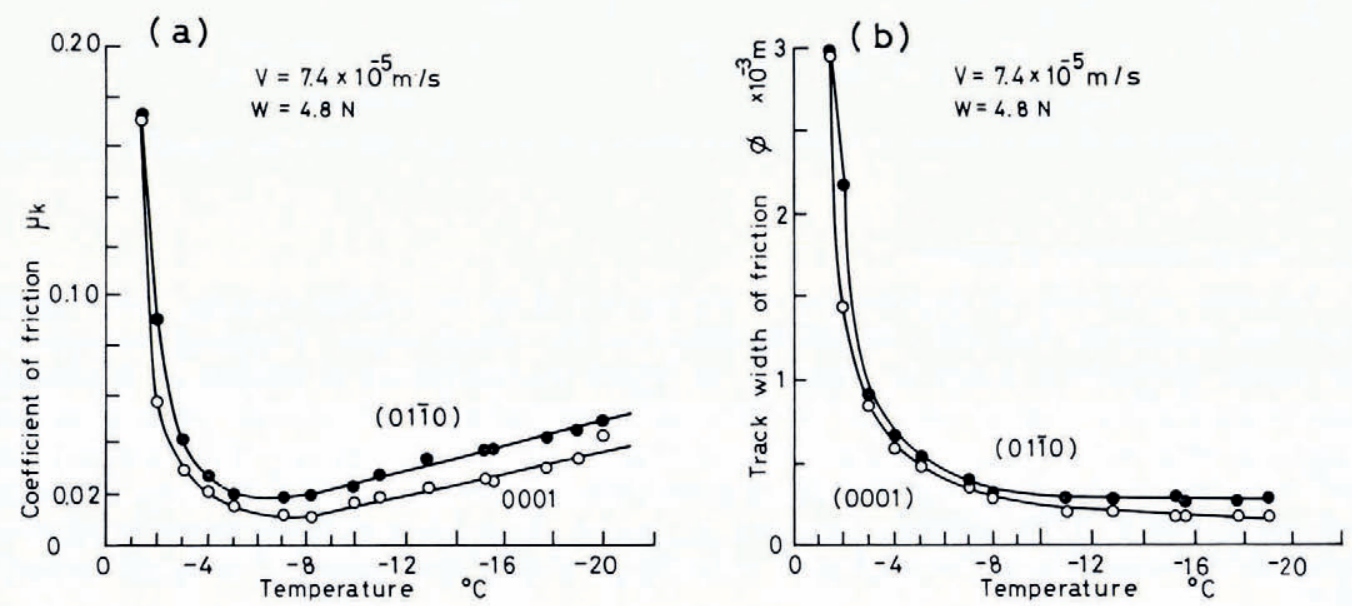

Fig. 6. (a) Dependence of friction on temperature, and (b) dependence of the width of the sliding track on temperature.

\section{(4) $\mu_{\mathrm{k}}-V-W$ diagram}

Dependence of the friction coefficient on the sliding velocity and load for a prismatic and a basal plane of ice are respectively summarized in Figure $7(a)$ and (b). The coefficient of friction ranged from 0.005 to 0.16 under the present experimental conditions. Though the friction varies with the friction velocity, load and temperature, it is much smaller than those observed for metals. The friction coefficient is much smaller for the basal plane than that for 
the prismatic plane for any experimental conditions. This may be due to the fact that the ice is very strong when it is compressed perpendicular to the basal plane, while it is very weak against a shearing force, which will be discussed later again.

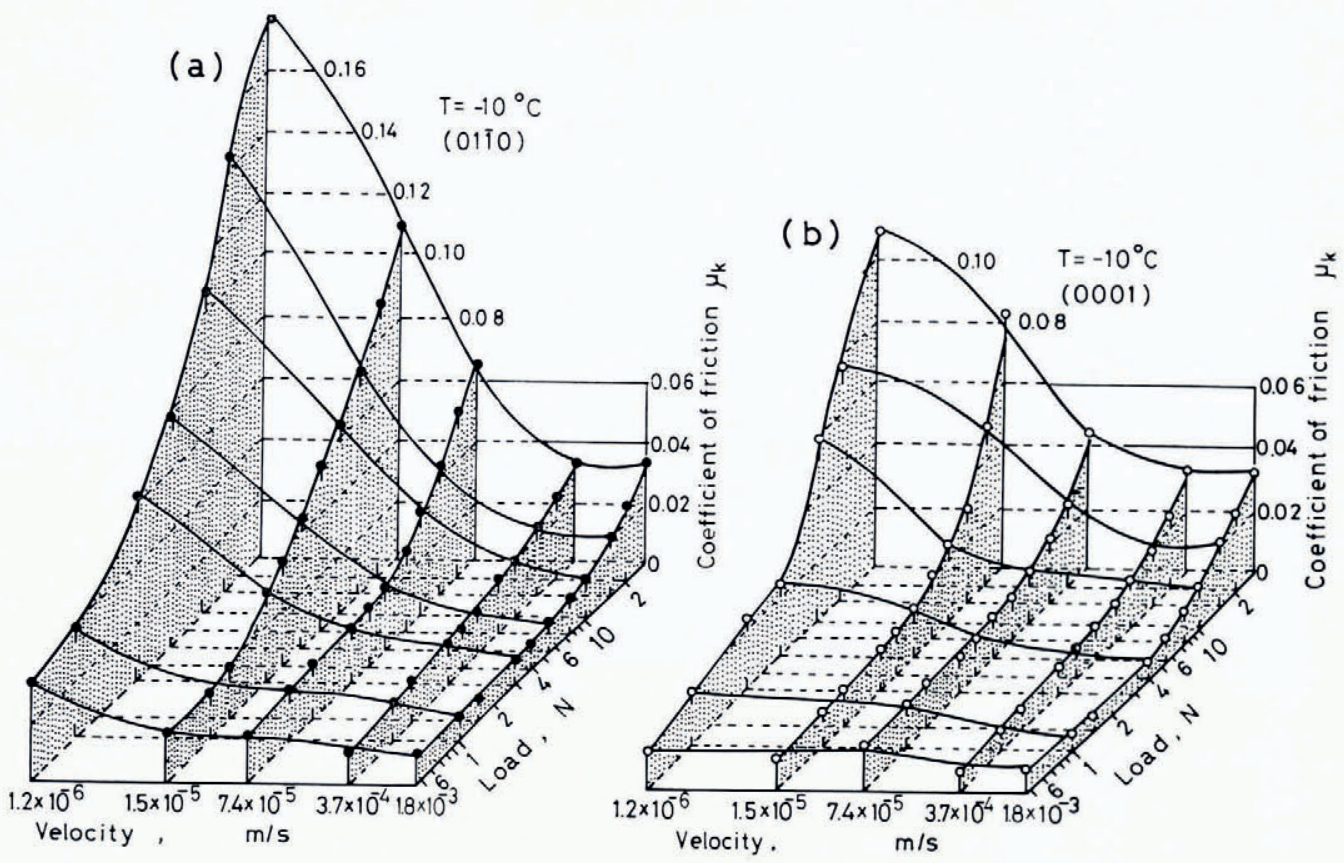

Fig. 7. $\mu_{\mathrm{k}}-V-W$ diagrams, (a) for a prismatic plane, and (b) for a basal plane.

\section{(5) Sliding track of friction}

As described before, it is important to measure the width of the sliding track left on the ice for interpreting the experimental results. The track width, the contact area, the average pressure acting on the contact area, and the cross-section ploughed for different loads are summarized in Table II.

The contact area $A$ can be expressed by using the track width $\phi$ as follows:

$$
A=\pi(\phi / 2)^{2} k \text {, }
$$

TABle II. SOME EXPERIMENTAL RESUlts OBTAINED IN THE EXPERIMENT ON FRICTION OF ICE AND THE PREDICTED VALUES OF THE SHEAR FRICTION $\mu_{8}$ AND THE PLOUGHING FRICTION $\mu_{\mathrm{p}}$

$$
\left.T=-10^{\circ} \mathrm{C}, V=7.4 \times 10^{-5} \mathrm{~m} / \mathrm{s} \text {, glacier ice (or } \overline{\mathrm{i}} \text { ) }\right), s=7 \text { bar, } p=1 \mathrm{O}^{3} \mathrm{bar}, K=0.8
$$

\begin{tabular}{|c|c|c|c|c|c|}
\hline $\begin{array}{c}\text { Load } \\
W \\
\mathrm{~N}\end{array}$ & $\begin{array}{l}\text { Coefficient of friction } \\
\mu_{\mathrm{k}}\end{array}$ & $\begin{array}{c}\text { Track width } \\
\phi \times \mathrm{IO}^{4} \\
\mathrm{~m}\end{array}$ & $\begin{array}{c}\text { Contact area } \\
\begin{array}{c}A \times \mathrm{I}^{7} \\
\mathrm{~m}^{2}\end{array}\end{array}$ & $\begin{array}{c}\text { Mean pressure } \\
p_{\mathrm{m}} \times \mathrm{IO}^{-2} \\
\mathrm{bar}\end{array}$ & $\begin{array}{c}\text { Ploughing area } \\
A^{\star} \times \mathrm{IO}^{8} \\
\mathrm{~m}^{2}\end{array}$ \\
\hline I. 4 & 0.020 & г. 6 & o. 16 & 9.0 & 0.011 \\
\hline 3.0 & 0.018 & 2.2 & 0.30 & $9 \cdot 7$ & 0.028 \\
\hline 4.0 & 0.021 & 2.9 & 0.53 & $7 \cdot 5$ & 0.064 \\
\hline 5.5 & 0.022 & 3.4 & 0.73 & $7 \cdot 5$ & 0.10 \\
\hline 8.0 & 0.026 & 3.7 & 0.85 & 9.2 & 0.13 \\
\hline I0.0 & 0.036 & 4.7 & 1.40 & $7 \cdot 5$ & 0.27 \\
\hline I6.0 & 0.043 & 5.8 & 2.10 & 7.6 & $0.5^{\mathrm{I}}$ \\
\hline 22.0 & 0.057 & 7.5 & 3.50 & 6.2 & 1. 10 \\
\hline 31.0 & 0.070 & 8.8 & 4.90 & 6.4 & 1. 80 \\
\hline
\end{tabular}

\begin{tabular}{ccc}
\multicolumn{3}{c}{ Calculated values } \\
$\mu_{\mathrm{s}}$ & $\mu_{\mathrm{p}}$ & $\left(\mu_{\mathrm{s}}+\mu_{\mathrm{p}}\right) / \mu_{\mathrm{k}}$ \\
& & \\
0.008 & 0.008 & 0.8 \\
0.007 & 0.009 & 0.9 \\
0.009 & 0.016 & 1.2 \\
0.009 & 0.018 & 1.2 \\
0.007 & 0.016 & 0.9 \\
0.009 & 0.026 & 1.0 \\
0.009 & 0.032 & 1.0 \\
0.011 & 0.050 & 1.1 \\
0.011 & 0.058 & 1.0
\end{tabular}


where $k$ is a factor which is dependent on the visco-elastic properties of the contact area, the value of $k$ being between 0.5 and r.o. Figure 8 shows the real contact area in the process of friction of a glass ball on ice. We know that the value of $k$ is equal to 0.8 from this Figure.

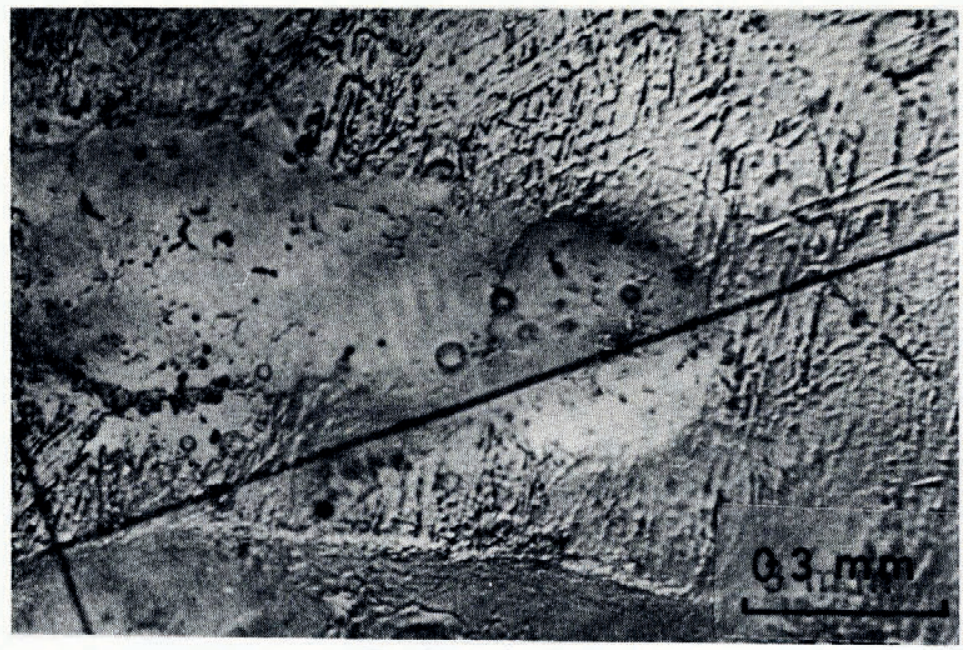

$$
\begin{aligned}
& \text { Glass ball-ice } \\
& T=-10^{\circ} \mathrm{C} \\
& V=7.4 \times 10^{-5} \mathrm{~m} / \mathrm{s} \\
& W=5.4 \mathrm{~N}
\end{aligned}
$$

Fig. 8. Real contact area in the process of friction.

\section{(6) Effect of the size of ball}

The degree of ploughing of ice by a steel ball may become larger as the ball becomes smaller in size. In order to examine the size effect of the steel ball on the friction coefficient of ice, steel balls of different diameters ranging from 1.6 to $12.7 \mathrm{~mm}$ were used as a slider. The experimental results obtained are shown in Figure 9, as an example, in which the friction coefficient $\mu_{\mathrm{k}}$ is plotted against the diameter $R$ of a ball. As was expected, the friction coefficient increased with the decrease in size of the ball for a smaller range of diameters than $9.5 \mathrm{~mm}$ when the load, the sliding velocity, and the temperature were $4.8 \mathrm{~N}, 7.4 \times 10^{-5} \mathrm{~m} / \mathrm{s}$ and $-10^{\circ} \mathrm{C}$, respectively. However, the friction remained unchanged when a steel ball larger than $9.5 \mathrm{~mm}$ in diameter was used.
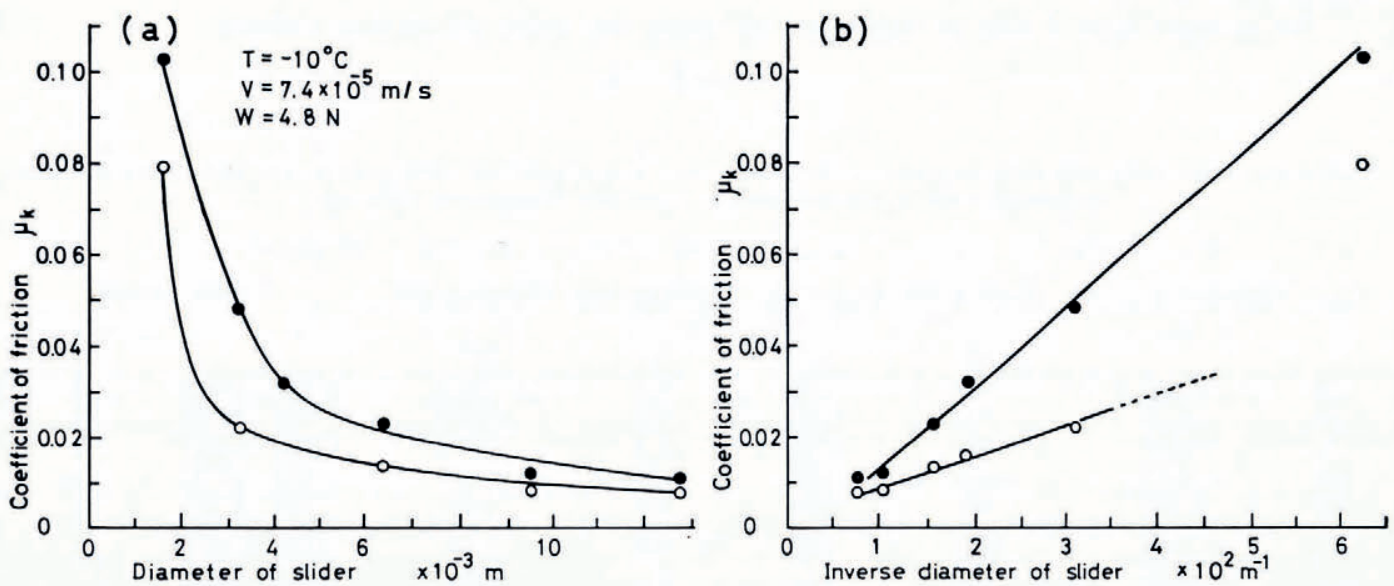

Fig. 9. Size effect on the friction of ice. 


\section{Discussion}

It was found that friction on ice is very low even at a very small friction velocity; namely the coefficient of friction $\mu_{\mathrm{k}}$ varied from 0.005 to 0.16 for friction velocities ranging from $\mathrm{I} .8 \times \mathrm{IO}^{-3}$ to $\mathrm{I} \times \mathrm{IO}^{-7} \mathrm{~m} / \mathrm{s}$. Such low friction on ice at extremely small friction velocities cannot be explained by frictional heating on the contact surface.

The temperature rise of ice, $\Delta \mathcal{T}$, due to friction can be expressed as follows (Bowden and Tabor, 1950):

$$
\Delta T=(\mu W V / 4 a) /\left(k_{1}+k_{2}\right),
$$

where $\mu$ is the coefficient of friction, $W$ the load applied, $V$ the friction velocity, $a$ the radius of the contact area and $k_{1}$ and $k_{2}$ the thermal conductivities of slider and ice. The maximum temperature rise $\Delta T$ predicted from this formula is only $0.3 \mathrm{deg}$ even when the maximum values of load $W$ and friction velocity $V$ used in the present experiment and the maximum value of friction coefficient 0.2 were substituted into the formula. It is obvious that the temperature rise due to frictional heating cannot cause melting of the ice.

It was also confirmed that melt water cannot be produced at the contact surface by pressure except at high temperatures.

According to adhesion theory, the frictional force $F$ on ice can be divided into the shear resistance $F_{\mathrm{s}}$ and the ploughing resistance $F_{\mathrm{p}}: F=F_{\mathrm{s}}+F_{\mathrm{p}}$. The coefficient of friction $\mu_{\mathrm{k}}$ $(=F / W)$ can, therefore, be written as the sum of the shear term $\mu_{\mathrm{s}}$ and ploughing term $\mu_{\mathrm{p}}: \mu_{\mathrm{k}}=\mu_{\mathrm{s}}+\mu_{\mathrm{p}}$.

According to Bowden and Tabor (1950), $F_{\mathrm{s}}$ and $F_{\mathrm{p}}$ were respectively given by:

$$
F_{\mathrm{s}}=\frac{k \pi \phi^{2} s}{4}, \quad F_{\mathrm{p}}=\frac{\phi^{3} p}{6 R},
$$

where $s$ and $p$ are respectively the shear and the ploughing strength of ice, $R$ is the diameter of slider, $\phi$ is the width of the sliding track and $k$ is a constant. The coefficient of friction $\mu_{\mathrm{k}}$ can, therefore, be expressed as

$$
\mu_{\mathrm{k}}=\frac{k \pi \phi^{2} s}{4 W}+\frac{\phi^{3} p}{6 W R} .
$$

As the first term, $\pi k \phi^{2} / 4 W$, and a part of the second term, $\phi^{3} / 6 R W$, are constant for a given load and a temperature, this formula can be simply expressed as

$$
\mu_{\mathrm{k}}=A+\frac{\alpha}{R},
$$

where $A$ and $\alpha$ are constant.

A linear relation was actually obtained between $\mu_{\mathrm{k}}$ and $\mathrm{I} / R$ in the experiment on the effect of slider size (Fig. 9(b)). This is evidence that the adhesion theory can be adopted for the friction of ice.

The values of $s$ and $p$ were estimated as follows: As described when considering the size effect, only a shear deformation took place in the contact area when a slider of diameter $R \geqslant 9.5 \mathrm{~mm}$ was used.

The shear strength $s$ is, therefore, given by $s={ }_{4} F / \pi k \phi^{2}$, where the value of $k$ is 0.8 as mentioned before. The value of the ploughing strength $p$ was estimated from Equation (5).

Since $\mu_{\mathrm{p}}=\phi^{3} p / 6 \mathrm{WR}$, the value of $p$ can be obtained by substituting values of $\phi, W$ and $R$ used in the experiment. The values thus obtained for $s$ and $p$ are io bar and 2 ooo bar, respectively. By substituting into the Equation (3) these values of $s$ and $p$, together with the experimental data obtained from Figure 5 , the values of $F_{\mathrm{s}}$ and $F_{\mathrm{p}}$, and hence those of $\mu_{\mathrm{s}}$ and $\mu_{\mathrm{p}}$ were obtained. These values are summarized in Table II, together with some experimental data obtained for various load. As seen in this table, the coefficient of shear friction 
$\mu_{\mathrm{s}}$ does not vary with load, while that of ploughing friction $\mu_{\mathrm{p}}$ increases markedly with the increase in the load. The predicted values of $\mu_{\mathrm{k}}\left(=\mu_{\mathrm{s}}+\mu_{\mathrm{p}}\right)$ agreed fairly well with those obtained by experiment for any load that ranged from $\mathrm{I} .4$ to $3 \mathrm{I} \mathrm{N}$ as seen from the last column of Table II in which the ratio of $\left(\mu_{\mathrm{s}}+\mu_{\mathrm{p}}\right)$ to $\mu_{\mathrm{k}}$ observed in the experiment was given. The fact that the predicted value based on the adhesion theory agreed well with those observed in the experiment affords additional strong evidence that the adhesion theory is adoptable for the friction of ice. The difference between friction on the basal and prismatic planes can be understood by the different values of $s$ and $p$ in the two planes as seen from Figure 9 . It should be emphasized that ice still exhibits a very low friction even though the ploughing effect is fairly large at very small sliding velocities.

\section{Acknowledgements}

The author wishes to express his deepest appreciation to Professor Wakahama and Professor Kuroiwa for their kind comments while conducting this study.

\section{REFERENCES}

Barnes, P., and others. 1971 . Friction and creep of polycrystalline ice, by P. Barnes, D. Tabor and J. C. F. Walker Proceedings of the Royal Society of London, Ser. A, Vol. 324, No. 1557, p. $127-55$.

Bowden, F. P. 1953. Friction on snow and ice. Proceedings of the Royal Society of London, Ser. A, Vol. 217 , No. 1131 , p. $462-78$.

Bowden, F. P. 1955. Friction on snow and ice and the development of some fast-running skis. Nature, Vol. 176, No. 4490 , p. $946-47$.

Bowden, F. P., and Hughes, T. P. 1939. The mechanism of sliding on ice and snow. Proceedings of the Royal Society of London, Ser. A, Vol. 172, No. 949, p. 280-98.

Bowden, F. P., and Tabor, D. 1950. The friction and lubrication of solids. Oxford, Clarendon Press.

Butkovich, T. R. 1954. Hardness of single ice crystals. U.S. Snow, Ice and Permafrost Research Establishment. Research Paper 9.

Evans, D. C. B., and others. 1976. The kinetic friction of ice, by D. C. B. Evans, J. F. Nye and K. J. Cheeseman. Proceedings of the Royal Society of London, Ser. A, Vol. 347, No. 1651, p. 493-512.

Huzioka [i.e. Fujioka], T. 1962. Yukizori no teiko. V [Studies on the resistance of snow sledge. V]. Teionkagaku: Low Temperature Science, Ser. A, [No.] 20, p. 159-79.

Huzioka [i.e. Fujioka], T. 1963. Yukizori no teiko. VI [Studies on the resistance of snow sledge. VI]. Teionkagaku: Low Temperature Science, Ser. A, [No.] 21, p. 3 I-44.

Joly, J. 1887. The phenomena of skating and Professor J. Thomson's thermodynamic relation. Scientific Proceedings of the Royal Dublin Society, New Series, Vol. 5, Pt. 6, p. 453-54.

Mantis, H. T., ed. 1951. Review of the properties of snow and ice. U.S. Snow, Ice and Permafrost Research Establishment. Report 4.

Niven, C. D. 1956. On the friction of heated sleigh runners on ice under high loading. Canadian Fournal of Technology, Vol. 34 , No. 4, p. 227-31.

Niven, C. D. 1959. A proposed mechanism for ice friction. Canadian Journal of Physics, Vol. 37, No. 3, p. $247-55$.

Pfalzner, P. M. 1947. The friction of heated sleigh runners on ice. Canadian fournal of Research, Section F, Vol. 25, No. 4 , p. $192-95$.

Raraty, L. E., and Tabor, D. 1958. The adhesion and strength properties of ice. Proceedings of the Royal Society of London, Ser. A, Vol. 245, No. 1241, p. 184-201.

Reynolds, O. 1899. On the slipperiness of ice. Memoirs and Proceedings of the Manchester Literary and Philosophical Society, Vol. 43, Pt. 2, No. 5 .

Schultz, H. H., and Knappwost, A. 1968. Die Festkörperreibung des Eises als Relaxationseffekt. Wear, Vol. I I, No. I, p. 3-20.

Shimbo, M. 1961. The mechanism of sliding on snow. Union Géodésique et Géophysique Internationale. Association Internationale d'Hydrologie Scientifique. Assemblée générale de Helsinki, 25-7-6-8 196o. Commission des Neiges et Glaces, p. 101-06. (Publication No. 54. de l'Association Internationale d'Hydrologie Scientifique.)

Tabor, D. 1961. Friction and adhesion between metals and other solids. (In Eley, D. D., ed. Adhesion. London, Oxford University Press, p. $115-36$.

Tabor, D., and Walker, J. C. F. I970. Creep and friction of ice. Nature, Vol. 228, No. 5267, p. 137-39.

Tusima [i.e. Tsushima], K., and Fuji 9 973. Kōri no sendan kyōdo no sokutei [Measurements of shear strength of ice]. Teion-kagaku: Low Temperature Science, Ser. A, [No.] 31, p. 33-43.

Tusima [i.e. Tsushima], K., and Yosida, Z. [i.e. Yoshida, J.] 1969. Kơri no masatu yūkai [Melting of ice by friction]. Teion-kagaku: Low Temperature Science, Ser. A, [No.] 27, p. 17-3o. 


\section{DISCUSSION}

D. J. Goodman: The experiments of Barnes and others (I97I) suggest that the adhesion of granite or glass is greater than that of steel. If an adhesion theory is proposed it would be most interesting to carry out these experiments (of low load and sliding speed) with these materials.

K. Tusima: I have done some experiments using plastic and glass balls. The friction of these was greater than that of the steel ball. However these less rigid balls were considerably deformed during the experiments and therefore the shapes of the frictional tracks were influenced better by the ice and the slider. Thus it is difficult to apply the adhesion theory quantitatively to the friction results for glass and plastic.

In friction between metals, the shear strength $s$ is nearly equal to the ploughing strength $p$. Therefore the ploughing effect can be neglected. However, in ice, $s$ is nearly equal to $p /$ I oo so the ploughing effect cannot be neglected.

L. Lliboutry: In order to obtain improved sliding of sledge runners at low temperatures, Rasmussen (1925, p. II4-I5) coated them with frozen peat and ice.

\section{REFERENCES}

Barnes, P., and others. 1971. Friction and creep of polycrystalline ice, by P. Barnes, D. Tabor and J. C. F. Walker. Proceedings of the Royal Society of London, Ser. A, Vol. 324, No. 1557, p. $127-55$.

Rasmussen, K. 1925. Fra Gronland til Stillehavet: rejser og mennesker fra 5. Thule-Ekspedition 1921-24. [Bd. I.] København, Gyldendalske Boghandel, Nordisk Forlag. 